\title{
East Asian 'Econophoria' in Theory and Practice
}

\author{
BRENDAN HOWE*
}

\begin{abstract}
'Econophoria' is the hope that the solution of all governance challenges, whether international or domestic, can be sought through economic growth and development. It is prevalent in the East Asian region, where tremendous economic development success stories have gone hand-in-hand with lengthy periods without interstate war. This paper explores the theoretical underpinnings and antecedents for econophoria, and how it has manifest in practice in East Asia. It also raises, however, a number of questions which challenge the underlying assumptions of peace though trade and economic growth paradigms in East Asia. How does the skewed wealth distribution that is associated with macro-economic growth affect the internal stability and peace of the societies in East Asia? Does this have an impact on the propensity of the governments to contain the conflicts they have with their neighbours at a level of low tension? Is the pursuit of economic growth prior to, or at the expense of, human rights and the wellbeing of the most vulnerable sustainable in the contemporary international operating environment?
\end{abstract}

Keywords: Econophoria, East Asia, Peace, Trade, Interdependence, Development

\footnotetext{
* Professor, Ewha Womans University, Seoul, South Korea;

E-mail: howeb@ewha.ac.kr

DOI: 10.16934/isr.17.1.201606.101
} 


\section{INTRODUCTION}

Barry Buzan and Gerald Segal coined the term 'econophoria' in reference to economic governance prioritization in East Asia whereby the solution of all society's ills is sought through economic growth and development $(1998,103)$. They further note, however, that while econophoria has contributed to remarkable patterns of economic growth, the prioritization of economic growth has also seen the rise in importance of challenges to human wellbeing in both absolute and relative terms (Buzan and Segal 1998, 107). Kenneth Christie and Denny Roy have also highlighted the prioritization of macroeconomic development in the region, noting that it 'has assumed cult-like status' in East Asia $(2001,5)$. Yet the prioritization of economic development in order to counter governance challenges has a lengthy theoretical and policy pedigree at both the domestic and international level, and in the 'West' as well as the 'East'. This paper explores the evolution of related international and domestic governance theoretical perspectives, the attempts to implement them (particularly in East Asia), and the ongoing governance challenges faced in the region despite, and in some cases as a result of 'econophoria.'

\section{PEACE THROUGH TRADE?}

Proponents of the trade paradigm in international relations claim that relations in the East Asian region support the validity of the assumptions on which they base their analysis. Although there are a number of political conflicts and even unresolved boarder issues between states in the region, there has been no major interstate war since the Korean armistice was signed in 1953. This general peaceful atmosphere prevails despite the absence of a comprehensive common security arrangement amongst the countries of the region, or any significant level of regional political cooperation.

The intellectual heritage of liberal thought on trade and peace can be traced to Emmanuel Kant. Indeed, Russet and O'Neal describe the liberal internationalist premises of peace through trade, the spread of democracy, and international organization, as the three sides of the Kantian triangle and have demonstrated the independent pacific effect of each, albeit with significantly less confidence with regard to the systemic effects of international governmental organizations (2001). The belief in peace through trade reached a false dawn with Normal Angell's 'Great Illusion,' in which he outlined how an intertwining of interests: complementary interests resulting from a division of labour (specialization), the cobwebstructure of monetary interests, and the complex relations between finance and trade, made war for profit an irrational undertaking (Angell 1913; 1938). The 'illusion' to which he referred was that military power could make a country wealthy, that the trade, territory and colonies of a defeated enemy could profitably 
be added to the wealth of the victor and that international interdependence could be disrupted without damaging trade (de Wilde 1989). Thus the more that countries developed and became dependent upon one another, the greater the costs of war, and the smaller the benefits that could be hoped to be gained from waging it.

Angell's work has been largely discounted due in the main to some unfortunate timing, with the first version published in 1913 on the eve of the First World War, and the second in 1938 on the eve of the Second World War (Papayoanou 1999). It is important to note, however, that he did not claim that war had become impossible, only that in economic terms it was no longer a rational enterprise, and that man, since he makes war, can also make wars cease (Angell 1935). His hypothesis therefore is not deterministic as such, but rather probabilistic. That is to say, economic considerations are but one of the calculations involved in the decision to go to war, and mutual interdependence through trade can cause this set of calculations in a rational decision-maker to be added to the peace side of the ledger during any cost-benefit analysis.

The critics of Norman Angell's hypothesis tend to be over-reliant on a single historical event, World War I, where comparatively high levels of economic interdependence proved insufficient to prevent war. Yet other surveys have found many instances where interdependence did serve to restrain foreign policy decisionmakers. Mark Gasiorowski and Solomon Polachek found 'a strong, inverse relationship between trade and conflict' $(1982,709)$. Their results indicated that international conflict could be eased considerably by 'engaging a hostile nation in interactions that are beneficial to it' (728). The 'anomaly' of the First World War can be explained in two ways: first that interdependency is an incremental process in which pacific pressures upon decision-makers are gradually ratcheted up until, in their cost-benefit rational calculations, it really is illogical for them to allow things to deteriorate to open warfare. Thus what may have been idealism a hundred years ago could be realistic now. The second answer, is that interdependence forms part of the operating environment within which decision-makers act, and the rational imperative not to go to war can be overridden by other personal or national interests, misperceptions or miscalculations. Given the multi-causal nature of the origins of warfare, economic interdependence does not make war impossible even if it does make it irrational from a cost-benefit analysis.

Economic interdependence is a function of mutual dependence between two or more states, the costs of which are exacerbated by conflict. The basic formulation is: [1] 'that war becomes irrational under interdependence, because it would endanger and in all probability destroy not only the adversary, but one's own interests and investments in his country as well: it would serve no rational purpose;' [2] 'that increasing cooperation and an increase in mutual dependency (in short, interdependence) will inevitably lead to an increase in the number of conflicts;' [3] but 'that under interdependence, the strategies of dealing with these conflicts will 
be restricted to non-violent and non-military ones' (Trompe 1989, 9-10).

The rationale for the crucial third hypothesis is that the costs of war resulting from the disruption to markets, investments, and flow of goods are exacerbated through interdependence as each dependent state is that much more vulnerable than it is under more autarkic conditions, while at the same time a culture of communication and compromise is fostered between mutually dependent dyads through repeated incidents and processes of cooperation. Furthermore, incentives for conflict are lower because 'in a relatively open liberal international economy, access to raw materials, finance, and markets is obtained at less cost and on a greater scale than would be possible via military control of territory or spheres of influence.' Thus: 'A liberal economic order divorces wealth and welfare from control over territory, and thereby removes one of the main reasons for the use of force' (Buzan and Segal 1998, 103). The process of interdependence is seen to operate at three levels: the global level, whereby the various processes of globalization have made all industrialized states interdependent and war-averse; the regional level, whereby certain regions of the world are seen to represent zones of economically induced peace; and the dyadic level, whereby mutual dependence between pairs of states is seen as reducing the likelihood, or even possibility of them going to war.

With regard to the first level of interdependence, that of globalization and economic development, Edward Morse contended as early as 1970, that: 'Foreign policy has been radically transformed by the revolutionary process of modernization not only in the societies composing the Atlantic region, but wherever high levels of modernization exist' $(1970,371)$. There is no doubt that high levels of modernization are being achieved throughout the Asian region, with first Japan, then the Asian Tigers, (South Korea, Hong Kong, Taiwan and Singapore) and finally China itself and the Asian Tiger Cubs (Thailand, Malaysia, Indonesia, the Philippines, and Vietnam) becoming increasingly integrated into the international economy.

At the turn of the millennium, a CIA publication analysing global trends leading to a world vision of 2015, saw the process of globalization picking up speed, and exceeding prior predictions. It noted international economic dynamics, including the development of the World Trade Organization (WTO), and the spread of information technology, as having much greater influence than previously anticipated, and predicted: 'The networked global economy will be driven by rapid and largely unrestricted flows of information, ideas, cultural values, capital, goods and services, and people' and that 'this globalized economy will be a net contributor to increased stability in the world.' In particular, 'Emerging Asia' was highlighted as the fastest growing region, led by breakout candidates China and India, whose economies already comprise roughly one-sixth of global GDP (CIA 2000, 5-25). 
At the regional level, commerce is spreading in East Asia. Not just the major modern capitalist export-driven economies of the region (Japan, South Korea, Taiwan and Hong Kong) but also the developing former socialist economies of Russia and Mongolia, the still nominally socialist economies of China and Vietnam, and even the Democratic People's Republic of Korea (DPRK), are driven to improve the lives of their citizens through selling what they can produce both globally and regionally (although what the DPRK is trading and trafficking may be considered inappropriate for a liberal and peaceful world order). Special economic zones are flourishing and most of the economies in the region are pressing to join global and regional economic organizations. Russia and China have long given up on autarky, and the Juche philosophy of the DPRK is failing so clearly that even the 'Dear Leader,' Kim Jong-il, appeared a convert to international trade. Thus he showed enthusiasm for a Buick plant near Shanghai, a consistent interest in establishing special economic zones, and an awareness and interest in the transition of both Russia and China (Gregg 2003). Despite ongoing tensions, increasing economic engagement (as detailed below) has been a consistent theme under Kim Jong-il's successor, Kim Jong-eun, as there is an awareness that the alternatives just don't work.

At the bilateral level the rationale is that the costs of war resulting from the disruption to markets, investments, and flow of goods are exacerbated through interdependence as each dependent state is that much more vulnerable than it is under more autarkic conditions. Thus mutual dependencies in trade, finance, and technology both raise the cost of conflict and lower the incentives for war. Simultaneously, a culture of communication and compromise is fostered between mutually dependent dyads through repeated incidents and processes of cooperation. In addition, increased economic interactions may contribute to a socializing effect.

Human beings have a natural tendency to fear the unknown. Fear of the unknown, as the common usage of the term xenophobia indicates, has the potential to generate hostility, or at the very least, worst-case scenarios conducive to realist or neorealist interpretations of international relations. According to such power political models, the rational position to take is one that assumes a struggle of all against all, the urge of others to dominate, and at least the possibility of war breaking out. Because in such a hostile, anarchic environment, it is not possible to trust or rely on the security guarantees of others, states and statesmen resort to self-help, and through the process of a security dilemma, where arming for selfdefence nevertheless poses a threat to others, realist models when put into actions become self-fulfilling prophesies. Yet increased economic interaction facilitates opposing sides getting to know one another, thereby reducing fear of the unknown, uncovering shared interests and possible mutual gains, and reducing another of the causes of war.

Although seemingly contradicted by the actions of authoritarian regimes and 
the analysis of realists during and after the inter-war 'twenty year crisis,' peace through trade may be seen as a paradigm born before its time, the tenets of which hold increasing relevance in a modern and interdependent world. This is particularly the case in the Northeast Asian security environment. Here there are few successful examples of diplomatic success in securing peace (the repeated collapse of the Six Party Talks on North Korea's nuclear and missile weapons programs, the failure of Japan and South Korea and Japan and China to resolve historic tensions and geographical borders, and the impasse over the status of Taiwan being just some of the high profile failures); the other sides of the virtuous triangle (democracy and international organization) seem in particularly scant supply; and yet there has been no major interstate war in Northeast Asia since the Korean armistice was signed in 1953. This general peaceful atmosphere prevails despite the absence of a comprehensive common security arrangement amongst the countries of the region or any significant level of regional political cooperation.

Increased economic interaction can also be seen to contribute positively to the evolution of a socially constructed community within which war becomes a more unlikely and unacceptable policy option. This, however, more properly forms part of the domestic political aspects of 'econophoria' addressed in the following section.

\section{A RISING TIDE LIFTS ALL BOATS?}

The relationship between economic development, democracy, and peace is complex in terms of directionality, with considerable disagreement as to whether development stimulates democracy or vice versa. In fact, the processes of economic development and democratization are probably mutually reinforcing. It is important at this juncture to consider the role of democratization as an intervening variable between trade and peace. Although democracies are not inherently more peaceful than authoritarian regimes, that democracies do not fight one another is as close to a natural law as we come in the social sciences. Thus if trade promotes economic growth, and economic growth stimulates democratization leading in turn to the development of more democratic dyads, it can be seen as contributing to peace in the region.

Although Japan had democratic institutions forced upon it, for the most part liberal internationalists have relied upon the appeal of democracy by convergence whereby the most fundamental question concerns 'how an almost universal wish to imitate a way of life associated with the liberal capitalist democracies of the core regions (the wish for modernity) may undermine the social and institutional foundations of any regime perceived as incompatible with these aspirations' (Whitehead 1996, 21). The great liberal hope for the region is that as China continues its phenomenal economic progress, a natural and inevitable bi-product 
will be the emergence of a true Chinese civil society that in turn will press for political liberalization. Lowell Dittmer predicts 'under such circumstances, previous experience suggests that a full-blown civil society-albeit still with distinctive Chinese cultural characteristics-is apt to emerge as quickly as bamboo shoots after a spring rain' (quoted in Nau 2002, 165). Zbigniew Brzezinski agrees, noting that: 'It is impossible to envision a long-term process of increasing economic pluralism without the appearance of civil society in China that eventually begins to assert its political aspiration' (ibid). With the US, Japan and Korea already consolidated democracies, a politically transformed China would not only lead to more democratic than conflictual dyads, but would also defuse the potential flash point with democratic Taiwan. The hope that even North Korea could be encouraged to liberalize politically in the event of being helped to develop economically was one of the underpinnings for South Korean President Kim Dae-jung's 'Sunshine Policy' and also the proposals for Northeast Asian energy cooperation.

Liberal optimism about the eventual pacific effects of modern capitalist development models is perhaps most famously summed up by Francis Fukuyama in his 'End of History' hypothesis, whereby a liberal victory in both the economic and political realms leads to a situation where there is no more ideological conflict (1989). The notion of democratic contagion from the West provides further support for this hypothesis (although given the geopolitical progression it should perhaps be called contagion from the East). In a similar manner to that feared by western Cold War strategists concerning the spread of communism, liberal economic and political transition has toppled one after another domino in the communist bloc. Democratic values have spread from America through Japan to South Korea, Taiwan, the Philippines, Indonesia, and Mongolia, and have even impacted upon China.

East Asian governments have also, however, focused on economic development for its own sake, for the potential benefit it can bring to national security and the wellbeing of the citizens of a country. This is where the aphorism 'a rising tide lifts all boats' comes into play. It is associated with the idea that improvements in the general economy will benefit all participants in that economy, and that economic policy, particularly government economic policy, should therefore focus on the general macroeconomic environment first and foremost. It is also associated with economic models which give tax breaks and other incentives to highearning individuals and corporations in the hope that they will generate wealth for all either directly, or through a 'trickle-down' effect. The concept of the rising tide can also be used however, in reference to the supposedly 'win-win' economic policies associated with neoliberalism including liberalization of financial markets, privatization, fiscal austerity, de-regulation, the enhancement of the role of the private sector, export-driven economic development measures, and the promotion of free trade. At various times, all governments in the region have pursued one or 
both of these econophoric policy agendas.

Macro-economic development models, policies and projects have been adopted by East Asian governments of all political persuasions, with various incarnations of the 'developmental state'. Perhaps the most famous apparent success story was the 'Miracle on the Han River' engineered in South Korea. After the Korean War (1950-1953), the country was devastated, and ranked as one of the poorest in the world with a GDP per capita of $\$ 67$ in 1953 , yet it has grown to become the world's fifteenth-largest economy. Initially, the developmental state led to signifycant progress in aggregate wellbeing, with GDP per capita rising from \$79 in 1960 to $\$ 5,438.24$ in 1989 (the $\$ 20,000$ milestone was reached in 2007). As a result, South Korea's infant mortality rate per 1,000 births (often used as a measure of how well a community is doing) fell dramatically from 115.6 in 1944 to 4.1 in 2009 (UN Population Division cited in Suh and Kim 2014, 55).

Following democratization in 1987, and the Asian financial crisis a decade later, South Korea adopted neoliberal market opening measures, as prescribed by the International Monetary Fund. Macroeconomic success continued. In 1995, South Korea graduated from being an aid recipient when it paid off its final structural adjustment loan to the World Bank, and it was removed from the Organisation for Economic Cooperation and Development (OECD)'s list of recipient nations in 2000. South Korea represents a rare case of an official development assistance (ODA) recipient success story: a country that has overcome the dual challenges of post-conflict underdevelopment and insecurity. In December 1996 the Republic of Korea (ROK) was able to join the OECD 'rich man's club,' and in November 2009, the Development Assistance Committee (DAC), marking the first instance of transition from recipient to donor.

In Taiwan, the nationalist Kuomintang (KMT) government of the Republic of China (ROC), having lost the Chinese civil war and been forced to retreat to the island, initially depended on US assistance in formulating and carrying out their version of the developmental state. At first this help seemed unlikely to materialize, since the US State Department blamed the military, civil, and economic incomepetence of the KMT government for the defeat in China and its subsequent loss of sovereignty over it. US policy regarding Taiwan changed with the outbreak of the Korean War, and the US government offered substantial economic and military aid and advice to Taiwan. The funds were earmarked for infrastructural projects, to finance the island's land reform, and to implement import-substitution industrialization. The ROC-US framework led to sustained rapid economic growth rates and egalitarian income distributions, which in turn provided the KMT with legitimacy to govern Taiwan and to represent its population (Schafferer 2014, 7576). By the mid-1960s, Taiwan's economy had become self-sustaining and US economic aid was suspended.

Japan was left similarly devastated after the Second World War, but led the 
way in terms of providing for national and regional economic development. Japan was the first East Asian country to graduate to membership of the Organisation for Economic Co-operation and Development (OECD) and also to join the Development Assistance Committee of the Organisation (OECD DAC), leading to unprecedented contributions to international development assistance and regional human security. Japan succeeded in becoming the world's second largest economy, and achieved a higher standard of living for its people than that enjoyed in the largest economy in the world. Not surprisingly, following Japan's remarkable post-war boom and evolution into an economic powerhouse, other regional economies looked to follow Tokyo's lead with policies such as Malaysia's 'Look East', and the 'Learn from Japan' campaigns of both Laos and Singapore contributing to a perception both within and outside the region of a 'flying geese' mode of East Asian capitalism with Japan as the lead goose.

Most recently, China has stolen the limelight with its dramatic economic rise and transition from sleeping dragon to regional powerhouse and potential global challenger (Lampton 2005, 74-75). As the Twentieth Century drew to a close, commentators were noting that there was no more important challenge for international affairs in the coming Asian century than to understand the nature and implications of a rising China (Segal and Goodman 1997, 1). Even if China fails to maintain its present staggering rate of economic growth (especially pertinent in the current climate), a more modest rate would still see it overtake America as the world's largest economy in the near future (if it has not by some measures already done so), and it has a massive internal captive market to insulate itself from any downturn in the global economy. Indeed, a number of studies predict that China's growing economic strength is such that not only will it overtake America as the world's leading economy, but it will also outstrip the declining hegemon to effect a power transition between them. According to The Economist (2008), by the years 2020-2040, China's economy will be about 40 percent larger than that of the United States. China has an unusual combination of high growth and deflation, the world's second highest foreign currency reserves, is now the number one steel producer in the world (among other commodities), and a large percentage of its exports are manufactured goods, suggesting a sound manufacturing and employment base.

The combination of the 1997 Asian financial crisis, and various aspects of globalization associated with the WTO and 24-hour stock market international financial regime, have seen a steady opening of the markets within the region, and a proliferation of free trade agreements involving states from the region. Thus the export-driven economies of Northeast Asia have increasingly adopted neoliberal market reforms. Econophoria has not, however, resulted in a universal win-win, nor has it necessarily de-escalated tensions in the region. The following sections consider ongoing domestic and international governance challenges despite, or 
perhaps even because of econophoria.

\section{HUMAN-CENTERED CHALLENGES}

On a general level, the consensual process of liberal transition championed by the likes of Francis Fukuyama is under threat. The western way of life only exerts a positive attraction as long as it is perceived to be desirable and preferable to other alternatives. Should the capitalist democratic world system enter a pronounced downturn (as perhaps heralded by the 2008 global financial crisis, or the current global financial turmoil) this may no longer be the case, particularly if increased inter-regional competition should lead to a new wave of protectionism and shrinking global trade. Furthermore, the promised benefits of liberal transition policies have been slower to materialize within transitional states than may have been hoped. An internal expectancy gap has developed within many transitional states, and in some cases, this could lead to a degree of discontent sufficient to undermine or even reverse the liberalization that has already taken place.

The processes of both economic and democratic transition are themselves sources of considerable uncertainty and hardship. Some groups are bound to lose out, at least in the short term. Support for transition is only generated by the general optimism that ultimately all will benefit; the hope that even if this is not the case, then at least the majority will do so; and the common belief held by most, that they will form part of this majority. The longer that uncertainty regarding the distribution of democratic spoils persists, the greater the chance of an authoritarian relapse (Pridham 1991). Thus economic transition may not lead to democratic consolidation and the formation of more peaceful democratic dyads. More than any other form of government, democracy depends for its legitimacy upon the consent of a majority of those governed. In order to generate and maintain such consent, democracy must provide what the majority of people want. Political perceptions vary in accordance with economic circumstances, and the inevitable costs of transition include corruption, inflation, underemployment of capital and labour, allocative inefficiencies and distributional effects (Maravall 1997). No matter the universal aspirations, no reform makes all better off, and certainly some will always benefit more than others. Any group that perceives itself worse off in relative, let alone absolute terms, is therefore likely to resist the implementation of the reform.

First we can turn to consider those states in Northeast Asia generally regarded to have reached the level of consolidated democracies (by international indices such as those used by Freedom House and Polity IV), as these would seem to provide the best case analysis for liberal models of governance. The problem is, that even these cases, South Korea, Japan, and Taiwan, see challenges to all the supposed benefits listed above as being associated with econophoria. In fact, 
Northeast Asian democratic governance has expanded in procedural terms but stalled in qualitative terms. Northeast Asian societies have further displayed reticence in democratic norms and culture. As a result, econophoria has not sufficiently improved the quality of life of many of the demos.

Democratic governance should function to reconcile the conflicting interests of all, and to generate their collective good. Governing in the interests of the people is not sufficient, as it denies equal participation to individuals and groups. If one is not empowered to participate fully, individual and community growth may be limited, but also, no matter how enlightened an elite is put in charge, they are unlikely to be sufficiently informed and concerned about the basic human needs and wants of the least empowered sections of society. Given the inherent danger of a dictatorship of the majority or the sacrifice of vulnerable groups in the interests of aggregate gain, truly 'good' democratic governance, would not only represent all sections of society, but would also empower them, and contain elements of distributive justice, whereby the needs of the least well-off are prioritized.

South Korea's initial rapid development was relatively equitable, certainly giving the impression of 'lifting all boats', but this began to change in the 1990s. The major turning point was the 1997 Asian financial crisis, during and after which economic inequality increased noticeably (Koo 2014). The neoliberal reform of the labour market over the past decade and a half produced a 'sharp cleavage between regularly employed workers on standard contracts and irregularly employed workers (those who are limited-term, part-time, temporary or dispatched)' (ibid). The latter group increased from 27.4 percent of the working population in 2002 to 34.2 percent in 2011. This means that approximately one third of South Korean workers suffer from insecure job conditions, including a lack of medical insurance, severance pay or company welfare subsidies, while receiving only around 60 percent of the wages of regular workers (ibid). Things are even worse for the majority of the growing number of foreigner migrant workers, who experience additional challenges related to a democratic deficit, hierarchical citizenship structure, limited access to social protection, discrimination, and a lack of political representation, right of association and collective action.

Poor democratic oversight and accountability has led to a culture of impunity among political and socio-economic elites of the 'Chaebol Republic.' This is reflected in construction catastrophes (bridges, department stores, apartment buildings, etc.); ferry disasters (the 1993 Seohae sinking left 292 dead, while in 2014, that of the Sewol led to a loss of 304 lives); subway fires and plane crashes; food and water safety scares. Lack of openness feeds the distrust of political figures; poor governance and information magnifies fear and actual impact of health scares such as MERS, SARS, BSE, and foot and mouth. In 2014, 5,869 Koreans died of automobile accidents, marking the 30th consecutive year that the number of fatalities from the epidemic has topped the 5,000 mark, and the highest 
rate in the OECD. Neoliberal economic policies have not led to universal win-win, but have contributed to the impact of a hyper-competitive society featuring stress, long hours at work, school, and hagwons, bullying at home, in school, at work, and in the army, and a suicide rate ranked as the highest in the world, with over 29 incidents per 100,000 of the population (OECD, 2012). As a result, one of the most popular trending terms in Korean social media is 'Hell Joseon' with 88 percent of young Koreans polled saying they hated their country and wanted to leave (Korean Media 2015).

In Japan, over the last two decades, the labour market has exhibited an increasing duality between regular and non-regular employment. Regular workers are typically hired immediately after school with the implicit promise of employment security until mandatory retirement age. Non-regular workers, by way of contrast, are usually hired on fixed-term contracts without the luxury of such employment security. Recent moves to deregulate the non-regular employment sector have resulted in a rapid growth in numbers of these disadvantaged citizens (Oh 2015, 87-88). Non-regular workers lack organizational strength, and thus representation. Weak representation has limited opportunities for non-regular workers to effectively participate in labour policymaking, with unions that represent non-regular workers generally excluded (88). Foreigners are substantially excluded from protection and empowerment and Koreans and indigenous groups are also substantially excluded or discriminated against. Japan has the second highest suicide rate in the OECD after ROK, and this is particularly prevalent among students and the elderly.

In Taiwan the Kuomintang (KMT) and its political allies have a 'pragmatic' approach to liberal democratic values, whereby nationalism and democracy are seen as means to obtain the ends of stability and economic growth. This 'pragmatic' view justifies the suspension of democratic principles should they no longer support these ends. Likewise, the concept of political tutelage promoted by the KMT assumes that the general public is incapable of making 'good' decisions and thus favours elite politics (Schafferer 2015, 128-129). This goes a long way to explaining the ambivalence of President Ma Ying-jeou towards democratic institutions. The process of acculturation or incomplete internalization of democratic values, combined with internal power struggles and political antagonism, led to the highlypublicized political turmoil during the Presidency of the Democratic Progressive Party (DPP)'s Chen Shui-bian. 'The KMT opposition sabotaged the democratic process, forgetting about their majority in parliament while pretending to be victims of a "fascist dictatorship" and engaging in spiteful civil disobedience' (ibid. 129). They were in fact the embodiment of the concept of a disloyal opposition. Thus in Taiwan democratic governance is hijacked by nationalism, state, and regime security, reducing the government's capacity to provide for the needs of the people.

Not surprisingly, if anything, the other regimes in Northeast Asia face even 
greater challenges. The People's Republic of China (PRC)'s unprecedented growth has been accompanied by unprecedented environmental challenges on an epic scale. 'Compounding these problems is the Chinese government's stony silence about anything that might imperil the country's economic development-including environmental regulation' (Lallanilla 2013). Food safety, water safety, air quality, all the foundational elements of human security which amount to the entitlement rights of the citizens, and impose obligations on those who govern, are challenged in the PRC. With tremendous economic growth has come not only environmental degradation, but also tremendous corruption, and macro-economic development projects frequently have a negative impact on human development and security.

Political pressures for increased public services are so strong and the current provision of education, health care, and pensions so inequitable and dysfunctional that the Chinese government will be compelled to continue to increase the share of output spent on these government services and transfers in the coming decades. Thus when these and other liabilities are recognized, they will significantly boost government debt. Meanwhile financing these increased expenditures will be problematic as taxes and government expenditures as a share of GDP are already above the average in medium-income developing countries and increased taxes could feed back into public discontent and unrest (Crane et al. 2005, xix). China already faces more than 90,000 protests annually as a result of endemic corruption and ongoing crises in public health and the environment (Economy 2008).

Challenges are most severe in North Korea. The DPRK's economic development was undermined by policy failures coupled with challenging regional and weather conditions. What the DPRK government attempted to build was an entirely self-sufficient economy that would need little outside trade (known as juche or self-reliance). Pyongyang aimed to produce everything within its borders through the total mobilization of its resources. The result was a centrally-planned economy that over-used all of its resources and often over-developed one sector to sustain others. Negative impacts were further exacerbated by the fact that North Korea simply did not possess sufficient resources of a requisite standard, and by unfortunate natural conditions and weather events. Soil degradation has reached the point where soil no longer holds together, which in turn has left the arable land of the entire country vulnerable to such climatic conditions as torrential rains or drought resulting in erosion. This means that the DPRK's current crises are not just due to natural factors, but also due to the way the economy has been developed. In addition, there is huge unevenness in the level of development between economic sectors. Prior to economic collapse, the country had developed a large heavy industry base for defence reasons while shortages of basic necessities were dire. The DPRK's centrally-planned economy has been unable to nurture its industrial sector with new sizeable investment for the last 30 years or so. International sanctions force the industrial sector to buy material and components at grossly inflated black 
market prices.

The DPRK's economy did begin to turn around in the 2000s, with a number of large investments in strategic areas. This was, at least in part, as a result of a shift away from the strict juche model of self-reliance. One area of divergence came with the establishment of 'Kaesong Industrial Complex' (KIC). The main purpose of the creation of such a large-scale industrial complex was to build the world's greatest 'International Free Economic City' combining South Korean capital and technology, and a predominantly North Korean labour force. Unfortunately, however, the Kaesong Industrial Complex does not seem to be fulfilling its initial purposes, or expectations that it will bring about significant advantages for both countries, and has become incredibly politicized.

In fact, the path of the KIC has never been smooth, with ongoing tensions undermining its neoliberal objectives since it first opened in 2004. The level of tensions increased significantly under the conservative administration of ROK president Lee, Myung-bak (in office 2008-2013), who supported stronger/tougher policies towards the DPRK, which may, indirectly, have led to the death of a ROK civilian at the hands of DPRK soldiers. Further deterioration of relations occurred in 2010 with attacks by North Korean forces on South Korea's Cheonan naval ship, and the shelling of Yeonpyeong Island which killed two civilians. That year's events caused a higher number of South Korean casualties than any other previous hostile actions since the Korean War, and it also raised security tensions in the Northeast Asian regions. Even liberal administrations in Seoul, which were seen as pursuing a softer line with Pyongyang, failed significantly to reduce tensions between North and South to the extent that the KIC could fulfil its promise and objectives. The challenges faced by the KIC are symptomatic of the region-wide challenges to the econophoric project at the international level. These are further addressed in the next section.

\section{A TWENTY-YEAR CRISIS IN NORTHEAST ASIA?}

As globalization rankings for all countries in the region remain low, especially when only economic indicators are considered, we need to consider the role of interdependence in the tighter, region-wide setting, or between dyads, rather than the global context (Kearney 2003; Foreign Policy 2007). For most of the region's economies, trade within Asia is becoming increasingly important as a percentage of total trade. The exception of China, however, is a large one. The region as a whole is faced with lopsided over-reliance on the U.S. market, unequal bilateral trading relationships between industrialized and emerging Asia, and also between the Chinese mega-economy and other states. This means (1) that pacific effects of intra-regional interdependence may not be felt; (2) that as rapidly developing countries fight for a share of the U.S. and Chinese markets, relations between 
them have the potential to deteriorate; and (3) that power relations are likely to reassert themselves.

The Northeast Asian subset is particularly problematic with a lack of free trade initiatives between any of the regional great powers (although the current South Korean administration is looking to change this). Countries in the sub-region in fact have far fewer cooperative economic arrangements than is the norm for economies of their scale and development, and the trading models of most of these countries remain tied more to economic nationalism and protectionism than the liberal capitalist model designed to boost integration and peace-hence the low economic freedom rankings for all but the United States.

Since China's accession to the WTO, her trading partners have become increasingly dissatisfied with its growing economic nationalism and failure to liberalize; in Japan and Korea international investment has been actively discouraged even to the extent of initiating legal procedures against foreign interests; and Russia has passed several laws limiting participation in its oil industry to local firms (Gamble 2006). In addition, the economies of Northeast Asia may not be ideally suited to promoting interdependence. On the one hand the variance in terms of size, structure, regulations, and levels of development of Northeast Asian economies may impede the free flow of trade and investment; on the other hand, Japan, China, South Korea and Taiwan may be too similar in terms of being mostly export-oriented producers of similar goods. Thus rapid development has not been matched by the evolution of peace-inducing interdependence.

Ian Bremmer et al. (2005) claim that the parallels of rising regional powers, territorial conflicts, and troubled bilateral relations could see Northeast Asia following a model analogous to Europe early in the twentieth century which set the continent on the road to 50 years of catastrophic violence. While in 2008 the world experienced an economic meltdown of a similar magnitude to that of the Wall Street crash, the region is currently entering its third such crisis within a generation. Japan, the economic powerhouse of the region, had only just recovered from a decade-long slump following the 1997-1999 Asian financial crisis, only to be faced with another manufacturing and export collapse of even greater magnitude. Asian stock markets are plummeting again. The benign era of liberal econophoria is threatened and regional if not global stability is seen by some as hanging by a thread as it did in Europe in the 1930s. The responses to economic crises of major economies could lead to a new round of economic national and further shrinkage of global trade, and thereby to a rise in conflictual forces.

Nationalism is certainly on the rise in Northeast Asia. New authoritarian tendencies are manifesting as politicians aim to shore up support undermined by internal governance shortcomings with appeals to the citizens to rally round the flag. This process can even amount to the generation of international instability in order to stimulate internal cohesion. We are used to such tactics from the likes of 
North Korea as it attempts to divert attention from its chronic shortcomings. Yet increasingly, hostility to ones neighbours is being manufactured across the region and it manifests in angry rhetoric, constitutional revision, policy initiatives, and public opinion polls.

North Korea has a long history of brinksmanship, including those incidents detailed above, and the roots of these military operations with far-reaching international security ramifications can be seen in domestic mass and elite politics (Howe 2013, 70). Yet the most recent crisis on the Korean Peninsula may have been escalated by South Korea as a diversion from the Seoul leadership's own domestic concerns. On August 9, 2015, two South Korean soldiers were wounded after stepping on landmines apparently laid by North Korean forces on the southern side of the DMZ next to a ROK guard post. South Korea responded by re-starting propaganda broadcasts from loudspeakers at the DMZ, a practice that both sides had previously agreed to discontinue. On August 20, North Korea fired a single $14.5 \mathrm{~mm}$ anti-aircraft shell at the offending speakers. South Korea responded by firing multiple shells from a $155 \mathrm{~mm}$ direct fire weapon. At the very least South Korea's responses may be seen as disproportionate-restarting a propaganda mechanism which had previously contributed to the escalation of tensions on the Peninsula, violating one of the few agreements between the two sides which up to that point had actually held up, and responding with multiple rounds of a much larger calibre. It may not be coincidental that the diversion of public attention towards the deteriorating situation at the DMZ came at a time when reports were due on electoral manipulation by the governing party and the National Intelligence Service.

As already mentioned, the KMT administration in Taiwan has long used the supposed threat of internal and external foes to undermine democracy and rally the people to defend the island's security. Similar processes are also now at work in Japan, however, with attempts at 'normalization' (for which opponents read 'militarization') being bolstered by the supposed threat of both North Korea and the People's Republic of China. Opinion polls have seen a steady deterioration of impressions of China, corresponding to an increased appreciation of Japan's security guarantor, and China's strategic rival, the United States. Yet the Tokyo government is not simply content to manipulate this trend, rather it is looking to lead it with policies far more radical than currently supported by public opinion.

A controversial secrecy bill, supposedly needed for national security, not only goes against the wishes of the majority of the demos (with as many as 80 percent opposing it), but it also undermines some of the vital checks and balances necessary for the functioning of transparent and accountable governance. It gives bureaucrats powers to withhold information that they deem secret, entirely at their own discretion, and with no effective oversight mechanism, grants the government powers to imprison whistle-blowers, prohibits disclosure of classified material 
even if in the public interest, and gives the government power to imprison journalists merely for soliciting information that is classified as secret (Kingston 2014). Furthermore, the increasingly authoritarian LDP administration would like to modify Article 21 of the Constitution, in which 'freedom of assembly and association as well as speech, press and all other forms of expression are guaranteed' with the proviso: 'Notwithstanding the foregoing, engaging in activities with the purpose of damaging the public interest or public order, or associating with others for such purposes, shall not be recognized' thereby not only stripping free speech protection from activities that might damage 'public order,' but also removing protection from the right of association (Repeta 2013).

Proposed modification of the supposedly pacifist constitution has raised concerns at home and abroad. Article 9 revisions include that Japan [1] maintain a modern military and that the government could deploy this force at home and abroad when it chose to do so; [2] would do away with the 'self-defence force' euphemism and replace it with 'national defence military' and would explicitly designate the Prime Minister as 'supreme commander'; [3] would delete the current prohibition on maintaining 'land, air and sea forces' and the renunciation of the 'right to belligerency' declaring that nothing in this provision would 'prevent the exercise of the right to self-defence' broadly defined and including 'activities to preserve the public order or to protect the lives or freedom of the people'; and [4] would grant the Prime Minister 'extraordinary powers' during a 'state of emergency' (Repeta 2013).

At the same time, the PRC has been increasing its military expenditure and capabilities dramatically every year for the last decade and a half. It has also developed a more assertive and outward-looking defence posture, no longer content simply to build fortifications sufficiently strong to deter any foreign power from attempting to repeat the former humiliation of the country. China is in the process of developing greater force projection capabilities (such as aircraft carriers), has set up bases around the region, and is of course increasingly assertive, if not outright belligerent, in the South China Sea. It is the driving force behind the Shanghai Cooperation Organization, seen by many as a counterweight to strategic partnerships cultivated by the United States. Anti-Japanese outbursts are increasingly common, and the government seems to do little to protect Japanese interests in the country from attack by Chinese citizens.

\section{CONCLUSION}

This paper has not set out to refute the fact that economic development and interdependence can contribute to domestic wellbeing and international peace. What it does is caution against viewing these processes through an econophoric lens as a panacea for all the governance challenges faced in the Northeast Asian 
region. Liberal economic policies can stimulate macroeconomic growth, but this does not necessarily translate into a universal win-win, or trickle down to the most vulnerable sections of society. Democratic transition and consolidation can be facilitated by good economic performance, but likewise can be undermined by underperformance.

Economic interdependence can facilitate peace, but can also, under some conditions, lead to increased conflict for limited resources or markets. Within the Northeast Asian region there remain serious questions as to the extent to which economic interdependence has been institutionalized. At the same time, even if economic interdependence can be seen as reducing the imperative for one of the causes of war, this cause is not the only reason why nations fight. There is even a danger that other causes of war (such as nationalism, or wars of diversion) can receive a boost as a result of the negative economic performance of poor domestic policies.

This framing theoretical paper, therefore, advocates a holistic approach to governance challenges by statesmen and scholars in the region, whereby all related phenomena are considered, and at all relevant levels (the international, the domestic, and the human), rather than just macroeconomic growth and trade policies at the state level.

\section{REFERENCES}

Angell, Norman. 1913. The Great Illusion. London: G. P. Putnam's Sons.

Angell, Norman. 1935. Nobel Lecture University of Oslo accessed March 16, 2016, $\mathrm{http} / / /$ nobelprize.org/nobel_prizes/peace/laureates/1933/angell-lecture.html Angell, Norman. 1938. The Great Illusion-Now. Harmondsworth: Penguin.

Bremmer, Ian, Sung-Hong Choi, and Yoriko Kawaguchi. 2005. "Northeast Asia: Defusing a Dangerous Region." International Herald Tribune.

Buzan, Barry and Gerald Segal. 1998. "Rethinking East Asian Security." In World Security: Challenges for a New Century edited by Michael T. Klare and Yohgesh Chandrani, New York: St. Martin's Press.

Central Intelligence Agency (CIA). 2000. Global Trends 2015: A Dialogue about the Future with Nongovernmental Experts accessed March 16, 2016, http:// www.cia.gov/cia/publications/globaltrends2015/index.html

Christie, Kenneth and Denny Roy. 2001. The Politics of Human Rights in East Asia. Chicago: University of Chicago Press.

Crane, Keith, Roger Cliff, Evan Medeiros, James Mulvenon, and William Overholt. 2005. Modernizing China's Military Opportunities and Constraints. RAND accessed March 16, 2016, http://www.rand.org/pubs/monographs/2005/ RAND_MG260-1.sum.pdf.

Economy, Elizabeth C. 2008. "Leadership Gap in China," Washington Post, Decem- 
ber 1. accessed March 16, 2016, http://www.washingtonpost.com/wp-dyn/ content/article/2008/11/30/AR2008113001690.html (accessed on Jan. 19, 2009). Economist, The. 2008. "China Moves to Centre Stage." October 30, accessed March 16, 2016, http://www.economist.com/displaystory.cfm?story_id = 12511197. Foreign Policy. 2007. Globalization Index Rankings for 2007, accessed March 16, 2016, http://www.foreignpolicy.com/story/cms.php?story_id $=4030$.

Fukuyama, Francis. 1989. "The End of History?” The National Interest 16: 3-18.

Gamble, William B. 2006. "Chinese Economic Nationalism.” International Assessment and Strategy Center, 12 December, accessed March 16, 2016, http:// www.strategycenter.net/research/pubID.130/pub_detail.asp.

Gasiorowski, Mark and Solomon Polachek. 1982. "Conflict and Interdependence." Journal of Conflict Resolution 26(4): 709-729.

Gregg, Don. 2003. "My Turn: Kim Jong Il-The Truth Behind the Caricature." in Newsweek February 3, accessed March 16, 2016, http://stacks.msnbc.com/ news/863858.asp.

Howe, Brendan M. 2013. The Promotion and Protection of Human Security in East Asia. Basingstoke: Palgrave Macmillan.

Kearney, A.T. (Management Consulting Firm) 2003. "Measuring Globalization: Who's Up, Who's Down?" Foreign Policy January/February: 60-72.

Kingston, Jeff. 2014. “Abe's Secrets Law Undermines Japan's Democracy.” in Japan Times, December 13 accessed March 16, 2016, http://www.japantimes.co.jp/ opinion/2014/12/13/commentary/japan-commentary/abes-secrets-law-under mines-japans-democracy/\#. VOaxnyamqUk.

Koo, Hagen. 2014. "Inequality in South Korea." in East Asia Forum July 1, accessed March 16, 2016, http://www.eastasiaforum.org/2014/07/01/inequality-in-sou th-korea/.

Korean Media. 2015. “'Hell Joseon'-88\% of Young Koreans Say South Korea is Hell, Want to Leave Korea for Other Countries." accessed March 16, 2016, https://www.reddit.com/r/korea/comments/31fl6h/hell_joseon_88_of_young_ koreans_say_south_korea/.

Lampton, David M. 2005. "Paradigm Lost: The Demise of Weak China." The National Interest 81: 73-80.

Lallanilla, Marc. 2013. “China's Top 6 Environmental Concerns.” In Livescience, last modified March 15, accessed March 16, 2016, http://www.livescience. com/27862-china-environmental-problems.html.

Maravall, Jose Maria. 1997. Regimes, Politics, and Markets: Democratization and Economic Change in Southern Europe and Eastern Europe. New York: Oxford University Press.

Morse, Edward. 1970. "The Transformations of Foreign Policies: Modernization, Interdependence and Externalization." World Politics 22(3): 371-92.

Nau, Henry. 2002. At Home Abroad: Identity and Power in American Foreign 
Policy. Ithaca: Cornell University Press.

OECD. 2012. Health Status, accessed March 16, 2016, https://data.oecd.org/heal thstat/suicide-rates.htm.

Oh, Jennifer S. 2015. "Non-Regular Workers in Japan." In Democratic Governance in Northeast Asia edited by Brendan M. Howe Basingstoke: Palgrave Macmillan.

Papayoanou, Paul. 1999. Power Ties: Economic Interdependence, Balancing, and War. Ann Arbor: University of Michigan Press.

Pridham, Geoffrey. 1991. Encouraging Democracy: The International Context of Regime Transition in Southern Europe. New York: St. Martin's Press.

Repeta, Lawrence. 2013. “Japan's Democracy at Risk: The LDP's Ten Most Dangerous Proposals for Constitutional Change." The Asia-Pacific Journal 11 (28/3).

Russet, Bruce and John O'Neal. 2001. Triangulating Peace: Democracy, Interdependence, and International Organizations. New York: Norton.

Schafferer, Christian. 2014. "Human Security and Post-Conflict Development in Taiwan." In Post-Conflict Development in East Asia edited by Brendan M. Howe Farnham: Ashgate Publishing.

Schafferer, Christian. 2015. "Debating 'Unpopular' Issues in Taiwan.” In Democratic Governance in Northeast Asia edited by Brendan M. Howe, Basingstoke: Palgrave Macmillan.

Segal, Gerald and David S. G. Goodman. 1997. China Rising. London: Routledge. Suh, Jae-jung and Jinkyung Kim. 2014. "Aid to Build Governance in a Fragile State: Foreign Assistance to a Post-Conflict South Korea." In Post-Conflict Development in East Asia, edited by Brendan M. Howe, Farnham: Ashgate Publishing.

Trompe, Hylke. 1989. "Interdependence, Security, and Peace Research.” In Interdependence and Conflict in World Politics edited by Rosenau, James N. and Hylke Tromp, Aldershot: Avebury.

Whitehead, Laurence. 1996. "Three international Dimensions of Democratization." In The International Dimensions of Democratization: Europe and the Americas edited by Laurence Whitehead, New York: Oxford University Press.

de Wilde, Jaap. 1989. "Norman Angell: Ancestor of Interdependence Theory.” In Interdependence and Conflict in World Politics edited by Rosenau, James N. and Hylke Tromp, Aldershot: Avebury. 